\title{
Associations of the apolipoprotein A-I gene polymorphism and serum lipid levels in the Guangxi Hei Yi Zhuang and Han populations
}

\author{
YIYANG LI $^{1}$, RUIXING YIN ${ }^{1}$, YIJIANG ZHOU ${ }^{1}$, YAJU DENG ${ }^{1}$, \\ DEZHAI YANG ${ }^{2}$, SHANGLING PAN ${ }^{3}$ and WEIXIONG LIN ${ }^{2}$ \\ ${ }^{1}$ Department of Cardiology, Institute of Cardiovascular Diseases, the First Affiliated Hospital, \\ ${ }^{2}$ Department of Molecular Biology, Medical Scientific Research Center, ${ }^{3}$ Department of Pathophysiology, \\ School of Premedical Sciences, Guangxi Medical University, Nanning 530021, P.R. China
}

Received January 28, 2008; Accepted March 3, 2008

\begin{abstract}
Hei Yi Zhuang is an isolated subgroup of the Zhuang minority in China. Little is known about the effects of the genetic variants on serum lipid profiles in this population. The present study was undertaken to estimate the effects of the apolipoprotein (apo) A-I gene polymorphism adjacent to the initiate transcription site (-75 bp G/A) on the serum lipid levels in the Hei Yi Zhuang and Han populations. A total of 474 subjects of Hei Yi Zhuang and 564 subjects of Han Chinese were surveyed by a stratified randomized cluster sampling. Serum lipid levels were measured, and apoA-I gene polymorphism determined by polymerase chain reaction and restriction fragment length polymorphism. The frequencies of $\mathrm{G}$ and $\mathrm{A}$ alleles were 70.25 and $29.75 \%$ in Hei Yi Zhuang, and 65.96 and $34.04 \%$ in Han $(\mathrm{P}<0.05)$, respectively. The genotypic frequencies in Han were significantly different between males and females, subjects with normal TG $(\leq 1.70 \mathrm{mmol} / \mathrm{l})$ and those with high TG $(>1.70 \mathrm{mmol} / \mathrm{l})$, or subjects with normal apoA-I $(\geq 1.20 \mathrm{~g} / \mathrm{l})$ and those with abnormal apoA-I $(<1.20 \mathrm{~g} / \mathrm{l} ; \mathrm{P}<0.05-0.01)$, respectively. The levels of LDL-C and apoA-I in Hei Yi Zhuang were higher in GG genotype than in AA or GA genotype ( $\mathrm{P}<0.05$ for each), but the levels of TG was lower in AA genotype than in GA genotype $(\mathrm{P}<0.05)$. There were also significant differences in serum TG levels among the three genotypes in Hei Yi Zhuang $(\mathrm{P}<0.05)$. The levels of HDL-C in Han were higher in GG genotype than in AA genotype $(\mathrm{P}<0.05)$, but the levels of $\mathrm{TG}$ in Han were lower in GG genotype than in GA genotype $(\mathrm{P}<0.05)$. The levels of apoA-I in Hei Yi Zhuang and the levels of HDL-C
\end{abstract}

Correspondence to: Dr Ruixing Yin, Department of Cardiology, Institute of Cardiovascular Diseases, Guangxi Medical University, 22 Shuangyong Road, Nanning 530021, Guangxi, P.R. China E-mail: yinruixing@yahoo.com.cn

Key words: apolipoprotein A-I, gene polymorphism, lipids, risk factors and apoB in Han were significantly correlated with genotype $(\mathrm{P}<0.05$ for all). Hypertriglyceridemia was negatively associated with genotype in Hei Yi Zhuang $(\mathrm{P}<0.01)$. There were significant differences in the apoA-I -75 bp G/A between the Hei Yi Zhuang and Han populations. An association of the apoAI -75 bp G/A and serum TG, LDL-C and apoA-I levels in Hei Yi Zhuang and serum TG, HDL-C and apoB levels in Han was also observed in this study.

\section{Introduction}

During the past 20 years, China has experienced remarkable socioeconomic development, with the mean income increasing by several fold. Consequently, the lifestyles of people throughout the country have changed dramatically. The nutritional changes have led to increased intake of fat and cholesterol contents which has gradually increased serum lipid levels. Disorders of lipid metabolism such as elevated serum levels of total cholesterol (TC) (1-3), triglycerides (TGs) (4,5), lowdensity lipoprotein cholesterol (LDL-C) $(6,7)$, apolipoprotein (apo) B (8-11), or low levels of high-density lipoprotein cholesterol (HDL-C) and apoA-I (12) have been considered to be important risk factors in the pathogenesis of atherosclerosis and coronary heart disease (CHD) (13). Clinical and epidemiological studies have demonstrated that plasma levels of HDL-C $(14,15)$ was negatively correlated with the risk of developing CHD. The protective effects of HDL-C and apoA-I are mediated mainly through the promotion of cholesterol efflux from peripheral cells (16-18). In addition, HDL has both anti-inflammatory and anti-oxidant properties $(15,19-21)$. ApoA-I is the predominant protein component of HDL-C, and is involved in the activation of lecithin: cholesterol acyltransferase, which mediate the reverse cholesterol transport from peripheral tissues to the liver. Human apoA-I gene resides in the apoAI-CIII-AIV gene cluster, a short region on chromosome 11q23-q24 (22). The apoAI-CIII-AIV gene cluster has been identified as an associated region with hyperlipidemia, especially with hypertriglyceridemia (23-25). A common MspI enzyme site 75 bp upstream from the initiate transcription site of human apoA-I gene was reported in $1990(26,27)$, relevance between serum lipid patterns and this polymorphism 
had been focused on since then. Extensive studies conducted on different races in different nations showed conflicting results (28-32). Serum lipid levels were decided by the interaction between gene variants and other factors such as race, environment exposure, diet, and lifestyle.

There are 56 ethnic groups in China. Han is the largest ethnic group, and Zhuang is the largest minority. Zhuang can be classified into 43 ethnic subgroups according to the differences in habitat and language. Hei Yi Zhuang is a specific subgroup of the Zhuang minority. The population size is 51,655 . Because of the isolation from other ethnic groups, the special customs and cultures including their clothing, inter-ethnic marriage, diet and lifestyle are still completely conserved. We have previously reported the differences in the serum lipid parameters $(33,34)$, and the associations of the microsomal triglyceride transfer protein gene, the lipoprotein lipase gene at $P v u I I$ locus and the variable number of tandem repeats region $3^{\prime}$ of the apoB gene polymorphism with the lipid profiles between the Hei Yi Zhuang and Han populations (35-37). We hypothesize that many genetic polymorphisms may be responsible for the differences in the serum lipid profiles between the two ethnic groups. Therefore, the aim of the present study was to assess the effect of the apoA-I -75 bp G/A polymorphism on serum lipid levels in the Guangxi Hei Yi Zhuang and Han populations.

\section{Materials and methods}

Subjects. A total of 474 subjects of Hei Yi Zhuang who reside in 7 villages in Napo County, Guangxi Zhuang Autonomous Region, China were surveyed by a stratified randomized cluster sampling. The age of the subjects ranged from 15 to 78 years, with an average age of $42.47 \pm 17.75$ years. There were 234 males $(49.37 \%)$ and 240 females $(50.63 \%)$. The subjects were peasants. During the same period, a total of 564 subjects of Han Chinese who reside in 9 villages in Napo County were also surveyed by the same method. The average age of the subjects was $42.03 \pm 17.21$ years (range 15-89). There were 279 males $(49.47 \%)$ and 285 females $(50.53 \%)$. They were also peasants. All study subjects were essentially healthy and had no evidence of diseases related to atherosclerosis. None of them had been treated with $\beta$-adrenergic blocking agents and lipid-lowering drugs such as statins or fibrates. The present study was approved by the Ethics Committee of the First Affiliated Hospital, Guangxi Medical University. Informed consent was obtained from all subjects after they received a full explanation of the study.

Epidemiological survey. The survey was carried out using internationally standardized methods, following a common protocol. Information on demographics, socioeconomic status, and lifestyle was collected with standardized questionnaires. Smoking status was categorized into groups of cigarettes per day: $<20$ and $\geq 20$. Alcohol consumption was categorized into groups of grams of alcohol per day: $\leq 25 \mathrm{~g}$ and $>25 \mathrm{~g}$. The physical examination included blood pressure, body height, and body weight, and body mass index (BMI) was calculated as weight $(\mathrm{kg})$ divided by height $(\mathrm{m})$ squared. Sitting blood pressure was measured three times with use of a mercury sphygmomanometer after the subjects had a 5-min rest, and the average of the three measurements was used in statistical analysis. Systolic blood pressure was determined by the first Korotkoff sound, and diastolic blood pressure by the fifth Korotkoff sound.

Measurements of serum lipid levels. Venous blood samples $(8 \mathrm{ml})$ were drawn from a forearm vein of every subject after venous occlusion for a few seconds in a sitting position, after an overnight fast of $12 \mathrm{~h}$ and abstention from alcohol use for at least $12 \mathrm{~h}$. Three $\mathrm{ml}$ was collected into glass tubes and allowed to clot at ambient temperature, and used to determine serum lipid levels, and the remaining $5 \mathrm{ml}$ was transferred to tubes with anticoagulate solution (ACD: $4.80 \mathrm{~g} / \mathrm{l}$ citric acid, $14.70 \mathrm{~g} / \mathrm{l}$ glucose, and $13.20 \mathrm{~g} / \mathrm{l}$ tri-sodium citrate) and used to extract deoxyribonucleic acid (DNA). Immediately following clotting serum was separated by centrifugation for $15 \mathrm{~min}$ at $3000 \mathrm{rpm}$. The levels of TC, TG, HDL-C, and LDL-C in samples were determined by enzymatic methods with commercially available kits, Tcho-1, TG-LH (RANDOX Laboratories Ltd., Ardmore, Diamond Road, Crumlin Co. Antrim, UK, BT29 4QY), Cholestest N HDL, and Cholestest LDL (Daiichi Pure Chemicals Co., Ltd., Tokyo, Japan), respectively. Serum apoA-I and apoB levels were assessed by the immunoturbidimetric immunoassay using a commercial kit (RANDOX Laboratories Ltd.). All determinations were performed with an autoanalyzer (Type 7170A; Hitachi Ltd., Tokyo, Japan) in the Clinical Science Experiment Center of the First Affiliated Hospital, Guangxi Medical University.

Deoxyribonucleic acid extraction. Genomic DNA was extracted from the peripheral blood leukocytes by applying phenol/chloroform method as follows: $5 \mathrm{ml}$ gelatine solution (3\% Gelatine and $0.5 \%$ EDTA in $7.5 \% \mathrm{NaCl}$ solution) was added into $2 \mathrm{ml}$ whole peripheral blood (with ACD antiagglutination), mixed and after incubating at $37^{\circ} \mathrm{C}$ for $10 \mathrm{~min}$, the supernatant was transferred to a clean tube, centrifuged in $3500 \mathrm{rpm}$ for $5 \mathrm{~min}$, then the supernatant was discarded and the pellet was homogenized with $2 \mathrm{ml}$ TES solution $(15 \mathrm{mM}$ Tris-HCl, $\mathrm{pH} 8.0 ; 15 \mathrm{mM} \mathrm{NaCl}$ and EDTA, $\mathrm{pH}$ 7.8). $0.1 \mathrm{ml}$ of $10 \%$ SDS was added and mixed, then added $2 \mathrm{ml}$ phenol, mixed and centrifuged $3500 \mathrm{rpm}$ for $5 \mathrm{~min}$. The supernatant was carefully transferred into a clean tube, chloroform/ isoamylic $(24: 1, \mathrm{v} / \mathrm{v}), 2 \mathrm{ml}$ was added, mixed and centrifuged $3500 \mathrm{rpm}$ for $5 \mathrm{~min}$. The supernatant was transferred into another clean tube, $95 \%$ ethanol $(5 \mathrm{ml})$ was gently added, mixed, the precipitated DNA was removed. The DNA was washed twice in $2 \mathrm{ml}$ of $70 \%$ ethanol and the pellet was stored at room temperature and suspended in 50-200 $\mu 1$ of $\mathrm{ddH}_{2} \mathrm{O}$ depending on the yield of the extracted DNA. The extracted DNA was stored at $4^{\circ} \mathrm{C}$ until analysis (35-37).

\section{Determination of the apoA-I gene polymorphism}

Amplification of genomic DNA. ApoA-I gene polymorphism was determined by polymerase chain reaction and restriction fragment length polymorphism (PCR-RFLP) according to previous reports (38). The sequence of the forward and backward primers used was 5'-CACCCGGGAGACCTGCA AGC-3' and 5'-TCTAAGCAGCCAGCTCTTGCA-3'. Each reaction system of a total volume of $25 \mu 1$, comprised $100 \mathrm{ng}$ 
(3 $\mu 1$ ) of genomic DNA, $0.8 \mu 1$ of each primer $(10 \mathrm{pmol} / \mu 1)$, $4 \mu 1$ of $10 \mathrm{X}$ buffer solution, $3 \mu \mathrm{dNTP}$, and $0.4 \mu 1$ (1 U) Taq polymerase. For the amplification, initial denaturation at $95^{\circ} \mathrm{C}$ for 5 min was followed by 30 cycles of denaturation at $95^{\circ} \mathrm{C}$ for $15 \mathrm{sec}$, annealing at $61^{\circ} \mathrm{C}$ for $1 \mathrm{~min}$, and extension at $72^{\circ} \mathrm{C}$ for $1 \mathrm{~min}$, with final extension at $72^{\circ} \mathrm{C}$ for $7 \mathrm{~min}$. Genomic DNA in the samples was amplified by PCR and imaged by $2 \%$ agarose gel electrophoresis, the target gene corresponding to bands at 259 bp could be identified in the samples (Fig. 1).

Genotyping of the apo AI -75 Msp I locus. A MspI enzyme site formed on the basis of the common $G$ allele at apoA-I 75 bp locus, whereas it disappeared when a $\mathrm{G} \rightarrow \mathrm{A}$ mutation happened at the locus. Each restriction enzyme reaction was performed with $15 \mu \mathrm{l}$ of amplified DNA; $2 \mu 1$ of $10 \mathrm{X}$ buffer solution; and $0.15 \mu 1(1.5 \mathrm{U}) \mathrm{MspI}$ restriction enzyme in a total volume of $20 \mu \mathrm{l}$ digested at $37^{\circ} \mathrm{C}$ overnight. The digested products were separated by electrophoresis on $4 \%$ sepharose gel for $60 \mathrm{~min}$ at $20 \mathrm{~mA}$. The length of each digested DNA fragment was determined by comparing migration of a sample with that of standard DNA marker. Stained with ethidium bromide, the gel was visualized under UV light and photographed. Genotypes were scored by an experienced reader blinded to epidemiological and lipid results. There were two MspI restriction sites on the PCR amplified products. One was at the $-75 \mathrm{bp}$ locus and another arose on the forward primer. The digestive products contained 4 bands: 254,176, 78 and 5 bp. The 5-bp fragment was invisible in the gel owing to its fast migration speed. The presence of the restriction site at -75 bp locus $(G)$ resulted in fragments of 254 and $5 \mathrm{bp}$. The genotypes identified were named after the presence or absence of the $-75 \mathrm{bp}$ enzyme restriction sites. Thus, GG was homozygote for the presence of this site (bands at 254,176, 78 and $5 \mathrm{bp}$ ), GA was heterozygotes for the presence and absence of the site (bands at 176,78 and $5 \mathrm{bp}$ ), and AA was homozygotes for the absence of the site (bands at 254 and $5 \mathrm{bp}$ ).

DNA sequencing. Genomic DNA was chosen from the subjects carrying GG, GA and AA of Hei Yi Zhuang and was amplified by symmetric PCR. The PCR product was purified by low melting point gel electrophoresis and phenol extraction. The products were analyzed by using an ABI PRISM 3100 (Applied Biosystems) in our Medical Scientific Research Center, Guangxi Medical University, China.

Diagnostic criteria. The normal values of serum TC, TG, HDL-C, LDL-C, apoA-I, and apoB in our Clinical Science Experiment Center were 3.10-5.17, 0.56-1.70, 1.04-1.81, 1.70-3.37 mmol/1, 1.20-1.60, and 0.63-1.14 g/l, respectively. Individuals with TC $>5.17 \mathrm{mmol} / \mathrm{l}$ and/or TG $>1.70 \mathrm{mmol} / \mathrm{l}$ were defined as hyperlipidemic. Hypertension was diagnosed according to the criteria of 1999 The World Health Organization-International Society of Hypertension Guidelines for the management of hypertension (39). The diagnostic criteria of overweight and obesity were according to the Cooperative Meta-analysis Group of China Obesity Task Force. Normal weight, overweight and obesity were defined as a BMI $<24$, $24-28$, and $>28 \mathrm{~kg} / \mathrm{m}^{2}$, respectively (40).

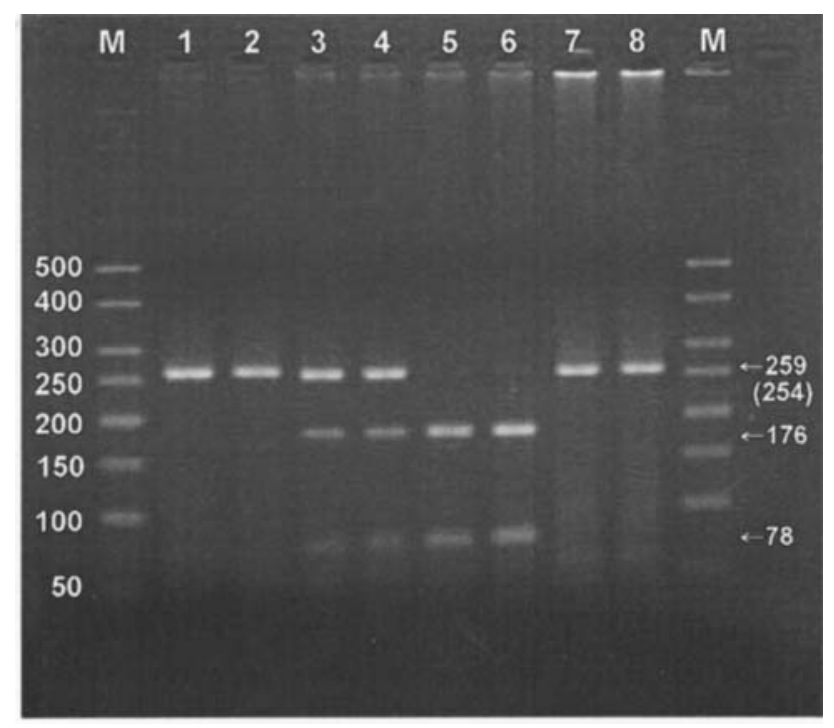

Figure 1. Computer-assisted photodocumentation showing examples of apo A-I -75 bp G/A polymorphic genotyping using Sepharose gel electrophoresis of PCR amplification products. Lane M, 50-bp DNA Ladder Marker; lanes 1 and 2, PCR amplificatied fragments (259-bp bands); lanes 3 and 4, GA genotypes (254-bp, 176- and 78-bp bands); lanes 5 and 6, GG genotypes (176- and 78-bp bands); lanes 7 and 8, AA genotypes (254-bp bands).

Statistical analysis. Epidemiological data were recorded on a pre-designed form and managed with Excel software. The quantitative variables were presented as mean \pm standard deviation (SD). The difference in general characteristics between Hei Yi Zhuang and Han was tested by the Student's unpaired t-test. The allele frequencies of the apoA-I -75G/A were determined by gene counting. The $\chi^{2}$ analysis was used to evaluate the allelic and genotypic frequencies that were calculated from the observed genotypic counts and to assess Hardy-Weinberg expectations. The association of genotypes with lipid variables was tested by analysis of covariance (ANCOVA). Sex, age, BMI, blood pressure, alcohol intake, cigarette smoking were adjusted for the statistical analysis. In order to evaluate the association of serum lipid levels with sex $($ male $=0$; female $=1)$, age (year), BMI $\left(\mathrm{kg} / \mathrm{m}^{2}\right)$, systolic blood pressure $(\mathrm{mmHg})$, diastolic blood pressure $(\mathrm{mmHg})$, pulse pressure (mmHg), cigarette smoking (cigarettes/day), alcohol consumption (g/day), A+/A- $(\mathrm{A}+=\mathrm{A}$ carriers, $\mathrm{A}-=$ non-carriers of A allele), and genotype $(\mathrm{GG}=0, \mathrm{GA}=1$, $\mathrm{AA}=2$ ), multiple linear regression analysis were executed with stepwise modeling. In addition, unconditional logistic regression analysis with forward stepwise modeling was used to analyze the relation between hypertriglyceridemia and sex $($ male $=0$; female $=1)$, age $(<20=1 ; 20-29=2 ; 30-39=3$; $40-49=4 ; 50-59=5 ; 60-69=6 ; \geq 70=7)$, BMI $\left(\mathrm{kg} / \mathrm{m}^{2}\right)$, systolic blood pressure $(\mathrm{mmHg})$, diastolic blood pressure $(\mathrm{mmHg})$, pulse pressure $(\mathrm{mmHg})$, cigarette smoking (non-smokers $=0$; $<20$ cigarettes/day $=1 ; \geq 20$ cigarettes $/$ day $=2$ ), alcohol consumption (non-drinkers $=0 ;<25 \mathrm{~g} /$ day $=1 ; \geq 25 \mathrm{~g} /$ day $=2$ ), $\mathrm{A}+/ \mathrm{A}-(\mathrm{A}+=\mathrm{A}$ carriers, $\mathrm{A}-=$ non-carriers of $\mathrm{A}$ allele $)$, genotype $(\mathrm{GG}=0, \mathrm{GA}=1, \mathrm{AA}=2)$. All statistical analyses were performed with the statistical software package SPSS 13.0 (SPSS Inc., Chicago, IL). A P $<0.05$ was considered significant. 
Table I. Comparison of demographic, lifestyle characteristics and serum lipid levels between Hei Yi Zhuang and Han.

\begin{tabular}{|c|c|c|c|c|}
\hline Characteristics & Hei Yi Zhuang & Han Chinese & $\mathrm{t}\left(\chi^{2}\right)$ & P-value \\
\hline Male/female & $234 / 240$ & $279 / 285$ & 0.001 & 0.974 \\
\hline Age (years) & $42.47 \pm 17.75$ & $42.03 \pm 17.21$ & -0.407 & 0.684 \\
\hline Height $(\mathrm{cm})$ & $151.62 \pm 10.93$ & $152.25 \pm 8.41$ & 1.030 & 0.303 \\
\hline Weight (kg) & $49.42 \pm 9.18$ & $51.59 \pm 8.31$ & 3.999 & 0.000 \\
\hline Cigarette smoking [n (\%)] & $153(32.3)$ & $180(31.9)$ & 0.016 & 0.901 \\
\hline Alcohol consumption $[\mathrm{n}(\%)]$ & $258(54.4)$ & $249(44.1)$ & 10.896 & 0.001 \\
\hline Body mass index $\left(\mathrm{kg} / \mathrm{m}^{2}\right)$ & $21.33 \pm 2.43$ & $22.18 \pm 2.61$ & 5.442 & 0.000 \\
\hline Systolic blood pressure (mm Hg) & $124.73 \pm 17.14$ & $119.91 \pm 15.44$ & -4.726 & 0.000 \\
\hline Diastolic blood pressure ( $\mathrm{mm} \mathrm{Hg}$ ) & $76.35 \pm 11.91$ & $75.35 \pm 9.12$ & -1.510 & 0.132 \\
\hline Pulse pressure $(\mathrm{mm} \mathrm{Hg})$ & $48.38 \pm 12.27$ & $44.59 \pm 10.74$ & -5.243 & 0.000 \\
\hline Total cholesterol $(\mathrm{mmol} / \mathrm{l})$ & $4.47 \pm 0.85$ & $4.76 \pm 0.99$ & 4.999 & 0.000 \\
\hline Triglycerides $(\mathrm{mmol} / \mathrm{l})$ & $0.88 \pm 0.51$ & $1.095 \pm 0.59$ & -6.859 & 0.000 \\
\hline HDL-C (mmol/l) & $2.12 \pm 0.50$ & $1.97 \pm 0.45$ & -4.732 & 0.000 \\
\hline LDL-C (mmol/l) & $2.22 \pm 0.63$ & $2.52 \pm 0.69$ & 7.288 & 0.000 \\
\hline Apolipoprotein (apo) A-I (g/l) & $1.45 \pm 0.14$ & $1.43 \pm 0.17$ & -2.152 & 0.032 \\
\hline Apo B $(g / l)$ & $0.85 \pm 0.21$ & $0.94 \pm 0.20$ & 7.418 & 0.000 \\
\hline Apo A-I/Apo B & $1.82 \pm 0.60$ & $1.57 \pm 0.33$ & -8.224 & 0.000 \\
\hline
\end{tabular}

HDL-C, high-density lipoprotein cholesterol; LDL-C, low-density lipoprotein cholesterol.

\section{Results}

General characteristics. Table I gives the general characteristics of the subjects between Hei Yi Zhuang and Han. The levels of systolic blood pressure, pulse pressure, and the percentage of subjects who consumed alcohol were higher in Hei Yi Zhuang than in Han ( $\mathrm{P}<0.01$ for all), whereas body weight and BMI were higher in Han than in Hei Yi Zhuang $(\mathrm{P}<0.01$ for each). There were no significant differences in body height, diastolic blood pressure, age, the percentage of subjects who smoked cigarettes, or the ratio of male to female between the two ethnic groups $(\mathrm{P}>0.05)$.

Serum lipid levels. As shown in Table I, the levels of TC, TG, LDL-C, and apoB in Hei Yi Zhuang were lower than those in Han $(\mathrm{P}<0.01)$, but the levels of HDL-C, apoA-I and the ratio of apoA-I to apoB in Hei Yi Zhuang were higher than those in Han $(\mathrm{P}<0.05-0.01)$.

Genotypic and allelic frequencies. Genotypic and allelic frequencies in the study groups are shown in Table II. The frequencies of $\mathrm{G}$ and $\mathrm{A}$ alleles were 70.25 and $29.75 \%$ in Hei Yi Zhuang, and 65.96 and $34.04 \%$ in Han $(\mathrm{P}<0.05)$, respectively. The frequencies of GG, GA and AA genotypes were 48.10, 44.30 and $7.60 \%$ in Hei Yi Zhuang, and 43.09, 45.74 and $11.17 \%$ in Han ( $>00.05)$, respectively. The genotypic frequencies in Han were significant differences between males and females, between subjects with normal TG $(\leq 1.70 \mathrm{mmol} / \mathrm{l})$ and subjects with high TG $(>1.70 \mathrm{mmol} / \mathrm{l})$, or between subjects with normal apoA-I ( $\geq 1.20 \mathrm{~g} / \mathrm{l})$ and subjects with abnormal
apoA-I ( $<1.20 \mathrm{~g} / \mathrm{l} ; \mathrm{P}<0.05-0.01)$, respectively. There were no significant differences in the remaining genotypic or allelic frequencies between Hei Yi Zhuang and Han, or between the subgroups of the same ethnic group. The GG, GA and AA genotypes shown by the PCR-RFLP method were also confirmed by direct sequencing (Figs. 2-4).

We also compared the differences in allelic frequencies between Hei Yi Zhuang and other ethnic groups in China, or other races in different countries (28-30,41-46). The frequency of the A allele was higher in Hei Yi Zhuang (0.297) than in Yi nationality (0.220) (41), Australian Caucasian (0.218) (42), Italian Caucasian (0.191) (30), Belgian Caucasian (0.181) (28), American Caucasian (0.157) (43), Finnish Caucasian (0.147) (44), or Icelandic Caucasian (0.124) (29) $(\mathrm{P}<0.01$ for all). However, there were no significant differences in the A allele frequency between Hei Yi Zhuang and Han Chinese in Beijing (45), or Singapore Chinese (46) (P>0.05 for each; Table III).

ApoA-I gene polymorphism and serum lipid levels. As shown in Table IV, the levels of LDL-C and apoA-I in Hei Yi Zhuang were higher in GG genotype than in AA or GA genotype $(\mathrm{P}<0.05$ for each). There were also significant differences in serum TG levels among the three genotypes in Hei Yi Zhuang $(\mathrm{P}<0.05)$. The levels of HDL-C in Han were higher in GG genotype than in AA genotype $(\mathrm{P}<0.05)$, but the levels of TG in Han were lower in GG genotype than in GA genotype $(\mathrm{P}<0.05)$. There were no significant differences in the remaining lipid parameters among the three genotypes in Hei Yi Zhuang, or in Han. 


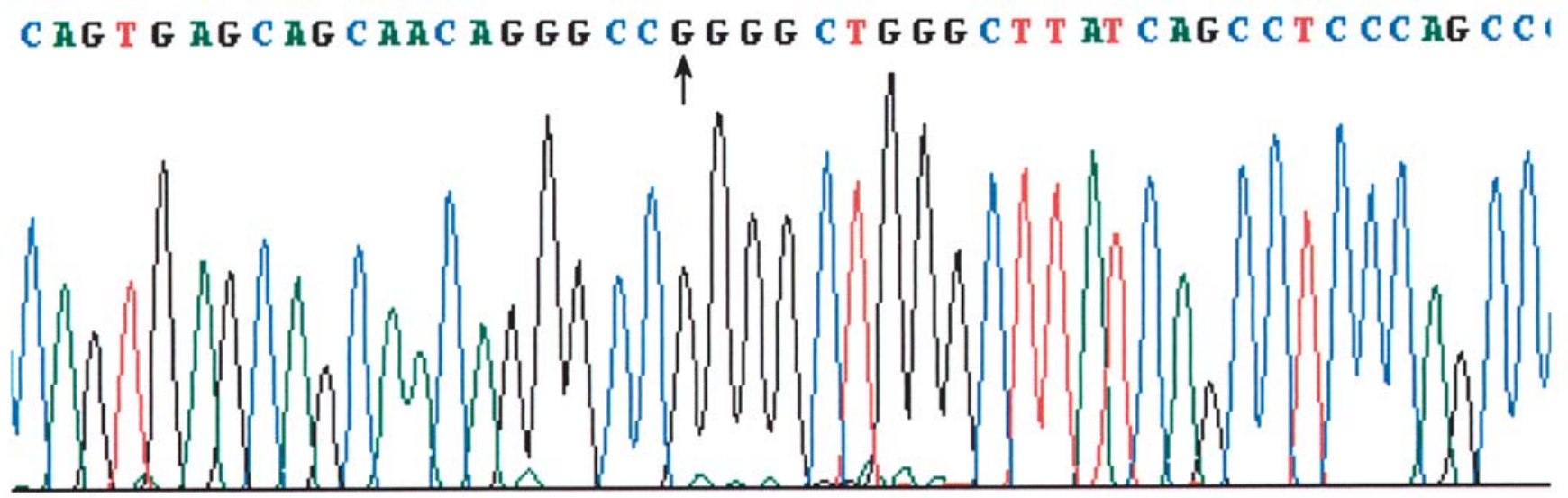

Figure 2. The GG homozygote of apo A-I -75 bp G/A SNP detected by sequencing. Arrow represented the G allele locus at apo A-I gene -75 bp.

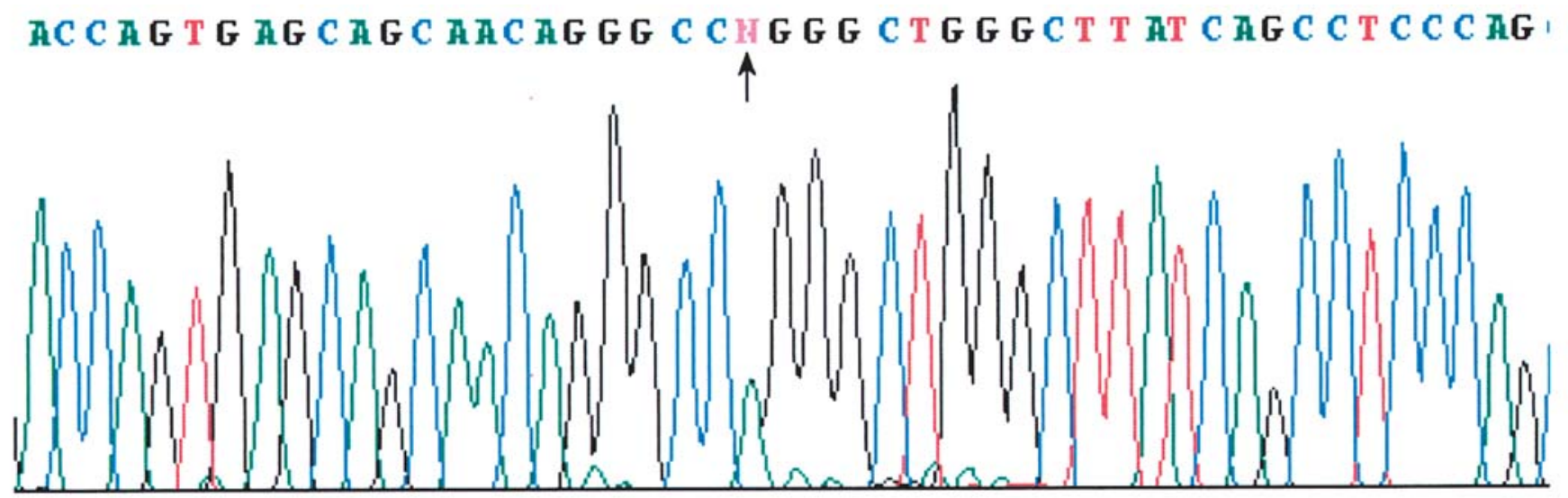

Figure 3. The GA heterozygote of apo A-I -75 bp G/A SNP detected by sequencing. Arrow represented the heterozygosity at apo A-I gene -75 bp locus.

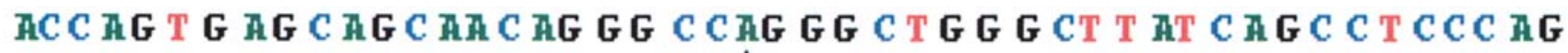
$\uparrow$

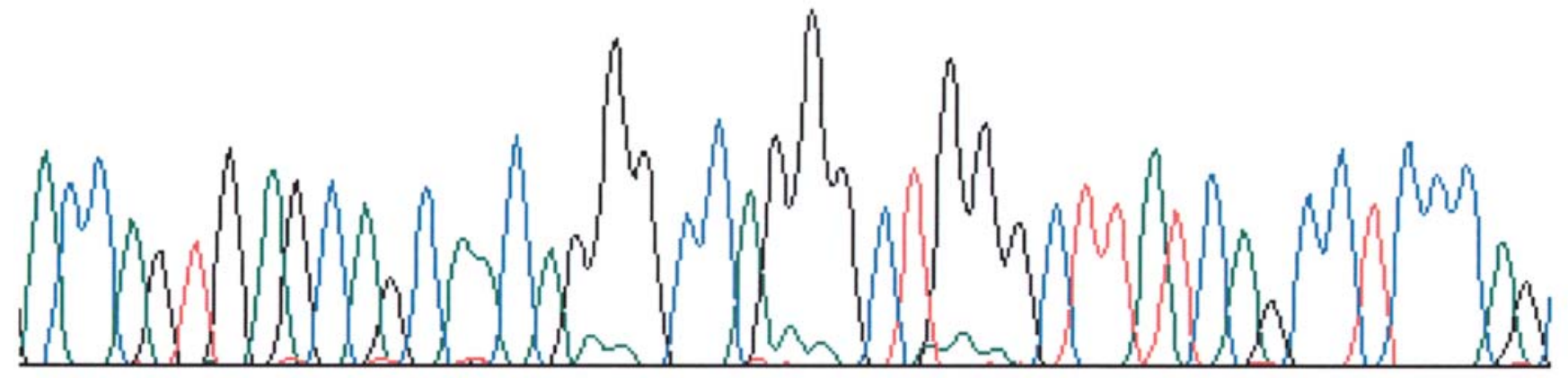

Figure 4. The AA homozygote of apo A-I -75 bp G/A SNP detected by sequencing. Arrow represented the A allele locus at apo A-I gene -75 bp.

Risk factors for serum lipid levels. Table $\mathrm{V}$ gives the correlative factors for serum lipid parameters between Hei Yi Zhuang and Han. The levels of TC, HDL-C, LDL-C, apoA-I, and apoB were significantly correlated with several environment factors such as age, sex, BMI, blood pressure, alcohol consumption, and cigarette smoking in both ethnic groups.
The levels of apoA-I in Hei Yi Zhuang and the levels of HDL-C and apoB in Han were significantly correlated with genotype $(\mathrm{P}<0.05$ for all).

Risk factors for hypertriglyceridemia. Unconditional multiple logistic regression analysis shows that hypertriglyceridemia 
Table II. Comparison of genotypic and allelic frequencies between the subgroups divided according to sex and the serum lipid levels.

\begin{tabular}{|c|c|c|c|c|c|c|}
\hline \multirow[b]{2}{*}{ Groups } & \multirow[b]{2}{*}{$\mathrm{n}$} & \multicolumn{3}{|c|}{ Genotypes [n (\%)] } & \multicolumn{2}{|c|}{ Alleles [n (\%)] } \\
\hline & & GG & GA & AA & G & A \\
\hline Hei Yi Zhuang & 474 & $228(48.10)$ & $210(44.30)$ & $36 \quad(7.60)$ & $666(70.25)$ & $282(29.75)$ \\
\hline Han Chinese & 564 & $243(43.09)$ & $258(45.74)$ & $63(11.17)$ & $744(65.96)$ & $384(34.04)$ \\
\hline$\chi^{2}$ & - & & 4.999 & & & \\
\hline P-value & - & & 0.082 & & & \\
\hline \multicolumn{7}{|l|}{ Hei Yi Zhuang } \\
\hline Male & 234 & $108(46.15)$ & $111(47.44)$ & $15(6.41)$ & $327(69.87)$ & $141(30.13)$ \\
\hline Female & 240 & $120(50.00)$ & $99(41.25)$ & $21 \quad(8.75)$ & 339 (70.63) & $141(29.37)$ \\
\hline$\chi^{2}$ & - & & 2.242 & & \multicolumn{2}{|c|}{0.064} \\
\hline P-value & - & & 0.326 & & \multicolumn{2}{|c|}{0.800} \\
\hline Normal TG & 420 & $198(47.14)$ & $186(44.29)$ & $36 \quad(8.57)$ & $582(69.29)$ & $258(30.71)$ \\
\hline High TG & 54 & $30(55.56)$ & $24(44.44)$ & 0 & $84(77.78)$ & $24(22.22)$ \\
\hline$\chi^{2}$ & - & & 5.333 & & \multicolumn{2}{|c|}{3.302} \\
\hline P-value & - & & 0.070 & & \multicolumn{2}{|c|}{0.069} \\
\hline Normal LDL-C & 447 & $210(46.98)$ & $201(44.97)$ & $36 \quad(8.05)$ & $621(69.46)$ & $273(30.54)$ \\
\hline High LDL-C & 27 & $18(66.67)$ & $9(33.33)$ & 0 & $45(83.33)$ & $9(16.67)$ \\
\hline$\chi^{2}$ & - & & 5.004 & & \multicolumn{2}{|c|}{4.688} \\
\hline P-value & - & & 0.082 & & \multicolumn{2}{|c|}{0.030} \\
\hline Normal Apo A-I & 378 & $174(46.03)$ & $174(46.03)$ & $30(7.94)$ & $522(69.05)$ & $234(30.95)$ \\
\hline Abnormal Apo A-I & 96 & $54(56.25)$ & $36(37.50)$ & $6 \quad(6.25)$ & $144(75.00)$ & $48(25.00)$ \\
\hline$\chi^{2}$ & - & & 3.206 & & & \\
\hline P-value & - & & 0.201 & & & \\
\hline \multicolumn{7}{|l|}{ Han Chinese } \\
\hline Male & 279 & $135(48.39)$ & $111(39.78)$ & $33(11.83)$ & $381(68.28)$ & $177(31.72)$ \\
\hline Female & 285 & $108(37.89)$ & $147(51.58)$ & $30(10.53)$ & $363(63.68)$ & $207(36.32)$ \\
\hline$\chi^{2}$ & - & & 8.103 & & \multicolumn{2}{|c|}{2.652} \\
\hline P-value & - & & 0.017 & & \multicolumn{2}{|c|}{0.103} \\
\hline Normal TG & 495 & $210(42.42)$ & $222(44.85)$ & $63(12.73)$ & $642(64.85)$ & $348(35.15)$ \\
\hline High TG & 69 & $33(47.83)$ & $36(52.17)$ & 0 & $102(73.91)$ & $36(26.09)$ \\
\hline$\chi^{2}$ & - & & 9.902 & & \multicolumn{2}{|c|}{4.432} \\
\hline P-value & - & & 0.007 & & \multicolumn{2}{|c|}{0.035} \\
\hline Normal LDL-C & 501 & $219(43.71)$ & $228(45.51)$ & $54(10.78)$ & $666(66.47)$ & $336(33.53)$ \\
\hline High LDL-C & 63 & $24(38.10)$ & $30(47.62)$ & $9(14.28)$ & $78(61.90)$ & $48(38.10)$ \\
\hline$\chi^{2}$ & - & & 1.081 & & \multicolumn{2}{|c|}{1.038} \\
\hline P-value & - & & 0.583 & & \multicolumn{2}{|c|}{0.308} \\
\hline Normal Apo A-I & 456 & $189(41.45)$ & $207(45.39)$ & $60(13.16)$ & $585(64.14)$ & $327(35.86)$ \\
\hline Abnormal Apo A-I & 108 & $54(50.00)$ & $51(47.22)$ & $3(2.78)$ & $159(73.61)$ & $57(26.39)$ \\
\hline$x^{2}$ & - & & 9.969 & & \multicolumn{2}{|c|}{6.970} \\
\hline P-value & - & & 0.007 & & \multicolumn{2}{|c|}{0.008} \\
\hline
\end{tabular}

TG, triglycerides; LDL-C, low-density lipoprotein cholesterol; Apo A-I, apolipoprotein A-I; normal TG, TG $\leq 1.70$ mmol/l; high TG, TG $>1.70 \mathrm{mmol} / \mathrm{l}$; normal LDL-C, LDL-C $\leq 3.37 \mathrm{mmol} / \mathrm{l}$; high LDL-C, LDL-C $>3.37 \mathrm{mmol} / \mathrm{l}$; normal Apo A-I, Apo A-I $\geq 1.20 \mathrm{~g} / \mathrm{l}$; abnormal Apo A-I, Apo A-I $<1.20 \mathrm{~g} / 1$. 
Table III. Comparison of allelic frequency between Hei Yi Zhang and various races.

\begin{tabular}{|c|c|c|c|c|c|}
\hline \multirow[b]{2}{*}{ Ethnic groups (refs.) } & \multirow[b]{2}{*}{$\mathrm{n}$} & \multicolumn{2}{|c|}{ Allele $[\mathrm{n}(\%)]$} & \multirow[b]{2}{*}{$\chi^{2}$} & \multirow[b]{2}{*}{ P-value } \\
\hline & & G & A & & \\
\hline Hei Yi Zhang & 474 & $666(0.703)$ & $282(0.297)$ & - & - \\
\hline Liangshan Yi (41) & 363 & $530(0.767)$ & $161(0.233)$ & 8.423 & 0.004 \\
\hline Beijing Han (45) & 450 & $668(0.742)$ & $232(0.258)$ & 3.623 & 0.057 \\
\hline Singaporean Chinese (46) & 287 & $416(0.725)$ & $158(0.275)$ & 0.858 & 0.354 \\
\hline Australian Caucasian (42) & 243 & $380(0.782)$ & $106(0.218)$ & 10.253 & 0.001 \\
\hline Italian Caucasian (30) & 204 & $330(0.809)$ & $78(0.191)$ & 16.526 & 0.000 \\
\hline Belgian Caucasian (28) & 144 & $236(0.819)$ & $52(0.181)$ & 15.311 & 0.000 \\
\hline American Caucasian (43) & 315 & $531(0.843)$ & $99(0.157)$ & 40.692 & 0.000 \\
\hline Finnish Caucasian (44) & 184 & $314(0.853)$ & $54(0.147)$ & 31.677 & 0.000 \\
\hline Icelandic Caucasian (29) & 315 & $552(0.876)$ & $78(0.124)$ & 64.819 & 0.000 \\
\hline
\end{tabular}

Table IV. Comparison of lipid levels among genotypes of Hei Yi Zhuang and Han.

\begin{tabular}{|c|c|c|c|c|c|c|c|}
\hline Genotypes & $\mathrm{n}$ & $\begin{array}{c}\mathrm{TC} \\
(\mathrm{mmol} / \mathrm{l})\end{array}$ & $\begin{array}{c}\mathrm{TG} \\
(\mathrm{mmol} / \mathrm{l})\end{array}$ & $\begin{array}{l}\text { HDL-C } \\
(\mathrm{mmol} / \mathrm{l})\end{array}$ & $\begin{array}{l}\text { LDL-C } \\
(\mathrm{mmol} / \mathrm{l})\end{array}$ & $\begin{array}{c}\text { ApoA-I } \\
(\mathrm{g} / \mathrm{l})\end{array}$ & $\begin{array}{c}\text { ApoB } \\
(\mathrm{g} / \mathrm{l})\end{array}$ \\
\hline \multicolumn{8}{|c|}{ Hei Yi Zhuang } \\
\hline GG & 228 & $4.56 \pm 0.83$ & $0.89 \pm 0.48$ & $2.17 \pm 0.52$ & $2.32 \pm 0.64^{b}$ & $1.46 \pm 0.13^{\mathrm{a}}$ & $0.87 \pm 0.20$ \\
\hline GA & 210 & $4.37 \pm 0.88$ & $0.91 \pm 0.69^{\mathrm{a}}$ & $2.07 \pm 0.48$ & $2.12 \pm 0.65$ & $1.44 \pm 0.16$ & $0.83 \pm 0.22$ \\
\hline $\mathrm{AA}$ & 36 & $4.47 \pm 0.78$ & $0.69 \pm 0.40$ & $2.05 \pm 0.51$ & $2.22 \pm 0.36$ & $1.41 \pm 0.13$ & $0.86 \pm 0.14$ \\
\hline$F$ & - & 1.620 & 4.413 & 2.281 & 5.398 & 3.999 & 1.549 \\
\hline P-value & - & 0.199 & 0.013 & 0.103 & 0.005 & 0.019 & 0.214 \\
\hline \multicolumn{8}{|c|}{ Han Chinese } \\
\hline GG & 243 & $4.71 \pm 1.04$ & $1.01 \pm 0.54$ & $2.00 \pm 0.48^{\mathrm{a}}$ & $2.50 \pm 0.68$ & $1.42 \pm 0.18$ & $0.92 \pm 0.21$ \\
\hline GA & 258 & $4.81 \pm 0.97$ & $1.17 \pm 0.64^{\mathrm{a}}$ & $1.97 \pm 0.45$ & $2.53 \pm 0.70$ & $1.43 \pm 0.16$ & $0.95 \pm 0.19$ \\
\hline $\mathrm{AA}$ & 63 & $4.71 \pm 0.86$ & $1.01 \pm 0.54$ & $1.89 \pm 0.31$ & $2.62 \pm 0.67$ & $1.42 \pm 0.13$ & $0.97 \pm 0.18$ \\
\hline$F$ & - & 0.297 & 4.892 & 3.953 & 1.319 & 0.729 & 1.968 \\
\hline P-value & - & 0.743 & 0.008 & 0.020 & 0.268 & 0.483 & 0.141 \\
\hline
\end{tabular}

TG, triglycerides; HDL-C, high-density lipoprotein cholesterol; LDL-C, low-density lipoprotein cholesterol; Apo A-I, apolipoprotein A-I; ${ }^{\mathrm{a}} \mathrm{P}<0.05$ in comparison with AA genotype of the same ethnic group; ${ }^{\mathrm{b}} \mathrm{P}<0.05$ in comparison with GA genotype of the same ethnic group.

was positively correlated with age and alcohol consumption, and negatively associated with genotype in Hei Yi Zhuang $(\mathrm{P}<0.05$ for all), whereas it was positively correlated with $\mathrm{BMI}$ and alcohol consumption in Han $(\mathrm{P}<0.001$ for each; Table VI).

\section{Discussion}

The results of the present study show that serum TC, TG, LDL-C and apoB levels were significantly lower in Hei Yi Zhuang than in Han, whereas the levels of HDL-C, apoA-I and the ratio of apoA-I to apoB in Hei Yi Zhuang were significantly higher than those in Han. These findings are consistent with those of our previous studies in a large population (34-37). Hei Yi Zhuang is an isolated subgroup of the Zhuang minority in China. Strict intra-ethnic marriages have been performed from time immemorial in this ethnic subgroup. Namely, only a man and a woman who are both Hei Yi Zhuang can marry, and can not intermarry with the other subgroups of Zhuang or other ethnic groups. Therefore, we are confident that some genetic polymorphisms may be involved in determing the serum lipid levels in this population.

In the present study, we showed that the frequency of $\mathrm{A}$ allele at the apoA-I -75 bp G/A was higher in Hei Yi Zhuang 
Table V. Relationship between the lipid parameters and relative factors in Hei Yi Zhuang and Han.

\begin{tabular}{|c|c|c|c|c|c|c|}
\hline Lipid parameters & Risk factors & $\mathrm{B}$ & Standard error & Beta & $\mathrm{t}$ & P-value \\
\hline \multicolumn{7}{|l|}{ Hei Yi Zhuang } \\
\hline \multirow[t]{3}{*}{$\mathrm{TC}$} & Age & 0.008 & 0.002 & 0.172 & 3.777 & 0.000 \\
\hline & Diastolic blood pressure & 0.015 & 0.003 & 0.213 & 4.591 & 0.000 \\
\hline & Gender & -0.213 & 0.077 & -0.125 & -2.755 & 0.006 \\
\hline \multirow[t]{3}{*}{ HDL-C } & Diastolic blood pressure & 0.010 & 0.002 & 0.240 & 5.360 & 0.000 \\
\hline & Alcohol consumption & 0.009 & 0.001 & 0.219 & 4.200 & 0.000 \\
\hline & Cigarette smoking & -0.007 & 0.003 & -0.110 & -2.131 & 0.034 \\
\hline \multirow[t]{4}{*}{ LDL-C } & Age & 0.006 & 0.002 & 0.160 & 3.610 & 0.000 \\
\hline & Body mass index & 0.038 & 0.012 & 0.146 & 3.291 & 0.001 \\
\hline & $\mathrm{A}+/ \mathrm{A}-$ & -0.179 & 0.056 & -0.141 & -3.201 & 0.001 \\
\hline & Gender & -0.149 & 0.056 & -0.118 & -2.645 & 0.008 \\
\hline \multirow[t]{5}{*}{ ApoA-I } & Age & 0.002 & 0.000 & 0.187 & 4.167 & 0.000 \\
\hline & Body mass index & 0.010 & 0.003 & 0.172 & 3.885 & 0.000 \\
\hline & Pulse pressure & -0.001 & 0.001 & -0.102 & -2.220 & 0.027 \\
\hline & Alcohol consumption & 0.008 & 0.005 & 0.239 & 5.578 & 0.000 \\
\hline & Genotype & -0.021 & 0.010 & -0.092 & -2.157 & 0.031 \\
\hline \multirow[t]{2}{*}{ ApoB } & Age & 0.002 & 0.001 & 0.215 & 4.839 & 0.000 \\
\hline & Body mass index & 0.013 & 0.004 & 0.156 & 3.504 & 0.001 \\
\hline \multicolumn{7}{|l|}{ Han Chinese } \\
\hline \multirow[t]{4}{*}{$\mathrm{TC}$} & Age & 0.012 & 0.002 & 0.202 & 4.853 & 0.000 \\
\hline & Body mass index & 0.071 & 0.015 & 0.189 & 4.673 & 0.000 \\
\hline & Diastolic blood pressure & 0.013 & 0.005 & 0.117 & 2.806 & 0.005 \\
\hline & Cigarette smoking & -0.014 & 0.005 & -0.119 & -2.967 & 0.003 \\
\hline \multirow[t]{5}{*}{ HDL-C } & Age & 0.004 & 0.001 & 0.168 & 4.016 & 0.000 \\
\hline & Body mass index & -0.032 & 0.007 & -0.187 & -4.598 & 0.000 \\
\hline & Diastolic blood pressure & 0.007 & 0.002 & 0.147 & 3.473 & 0.001 \\
\hline & Gender & -0.129 & 0.037 & -0.143 & -3.507 & 0.000 \\
\hline & Genotype & -0.062 & 0.027 & -0.091 & -2.280 & 0.023 \\
\hline \multirow[t]{4}{*}{ LDL-C } & Age & 0.007 & 0.002 & 0.186 & 4.097 & 0.000 \\
\hline & Body mass index & 0.038 & 0.011 & 0.144 & 3.521 & 0.000 \\
\hline & Systolic blood pressure & 0.004 & 0.002 & 0.097 & 2.104 & 0.036 \\
\hline & Alcohol consumption & -0.056 & 0.024 & -0.122 & -2.886 & 0.004 \\
\hline \multirow[t]{5}{*}{ ApoA-I } & Age & 0.002 & 0.000 & 0.178 & 4.242 & 0.000 \\
\hline & Body mass index & -0.007 & 0.003 & -0.105 & -2.591 & 0.010 \\
\hline & Diastolic blood pressure & 0.003 & 0.001 & 0.158 & 3.687 & 0.000 \\
\hline & Alcohol consumption & 0.002 & 0.000 & 0.117 & 2.753 & 0.006 \\
\hline & Cigarette smoking & -0.003 & 0.001 & -0.155 & -3.777 & 0.000 \\
\hline \multirow[t]{4}{*}{ ApoB } & Age & 0.002 & 0.000 & 0.185 & 4.606 & 0.000 \\
\hline & Body mass index & 0.016 & 0.003 & 0.214 & 5.277 & 0.000 \\
\hline & Cigarette smoking & -0.003 & 0.001 & -0.119 & -2.950 & 0.003 \\
\hline & Genotype & 0.028 & 0.012 & 0.093 & 2.306 & 0.021 \\
\hline \multicolumn{7}{|l|}{$\backslash$} \\
\hline \multicolumn{7}{|l|}{ Hei plus Han } \\
\hline \multirow[t]{4}{*}{$\mathrm{TC}$} & Age & 0.010 & 0.002 & 0.186 & 6.121 & 0.000 \\
\hline & Gender & -0.151 & 0.056 & -0.080 & -2.675 & 0.008 \\
\hline & Body mass index & 0.054 & 0.011 & 0.148 & 4.862 & 0.000 \\
\hline & Diastolic blood pressure & 0.013 & 0.003 & 0.140 & 4.485 & 0.000 \\
\hline
\end{tabular}


Table V. Continued.

\begin{tabular}{|c|c|c|c|c|c|c|}
\hline Lipid parameters & Risk factors & B & Standard error & Beta & $\mathrm{t}$ & P-value \\
\hline \multirow[t]{8}{*}{ HDL-C } & Age & 0.003 & 0.001 & 0.094 & 2.904 & 0.004 \\
\hline & Gender & -0.072 & 0.034 & -0.075 & -2.131 & 0.033 \\
\hline & Body mass index & -0.017 & 0.006 & -0.093 & -3.015 & 0.003 \\
\hline & Diastolic blood pressure & 0.009 & 0.001 & 0.194 & 6.039 & 0.000 \\
\hline & Pulse pressure & -0.003 & 0.001 & -0.064 & -2.017 & 0.044 \\
\hline & Cigarette smoking & -0.005 & 0.002 & -0.079 & -2.251 & 0.025 \\
\hline & Alcohol consumption & 0.010 & 0.002 & 0.160 & 4.801 & 0.000 \\
\hline & Genotype & -0.066 & 0.022 & -0.089 & -3.017 & 0.003 \\
\hline \multirow[t]{5}{*}{ LDL-C } & Age & 0.006 & 0.001 & 0.161 & 4.981 & 0.000 \\
\hline & Gender & -0.097 & 0.042 & -0.072 & -2.296 & 0.022 \\
\hline & Body mass index & 0.038 & 0.008 & 0.144 & 4.824 & 0.000 \\
\hline & Systolic blood pressure & 0.003 & 0.001 & 0.069 & 2.108 & 0.035 \\
\hline & Alcohol consumption & -0.099 & 0.046 & -0.074 & -2.338 & 0.020 \\
\hline \multirow[t]{5}{*}{ Apo A-I } & Age & 0.002 & 0.000 & 0.175 & 5.424 & 0.000 \\
\hline & Gender & -0.033 & 0.010 & -0.105 & -3.349 & 0.001 \\
\hline & Diastolic blood pressure & 0.002 & 0.000 & 0.139 & 4.406 & 0.000 \\
\hline & Pulse pressure & -0.001 & 0.000 & -0.066 & -2.101 & 0.036 \\
\hline & Alcohol consumption & 0.004 & 0.001 & 0.190 & 5.956 & 0.000 \\
\hline \multirow[t]{3}{*}{ Apo B } & Age & 0.002 & 0.000 & 0.188 & 6.448 & 0.000 \\
\hline & Gender & -0.035 & 0.012 & -0.084 & -2.885 & 0.004 \\
\hline & Body mass index & 0.015 & 0.002 & 0.182 & 6.127 & 0.000 \\
\hline
\end{tabular}

TC, total cholesterol; HDL-C, high-density lipoprotein cholesterol; LDL-C, low-density lipoprotein cholesterol; Apo A-I, apolipoprotein A-I; ApoB, apolipoprotein B; A+, A carriers; A-, non-carriers of A allele; B, unstandardized coefficient; Beta, standardized coefficient.

Table VI. Risk factors of hypertriglyceridemia in Hei Yi Zhuang and Han.

\begin{tabular}{llccrrr}
\hline Ethnic groups & \multicolumn{1}{c}{ Risk factors } & Regression coefficient & Standard error & Odds ratio & Wald & P-value \\
\hline \multirow{2}{*}{ Hei Yi Zhuang } & Age & 0.197 & 0.087 & 1.217 & 5.069 & 0.024 \\
& Alcohol consumption & 0.554 & 0.183 & 1.740 & 9.202 & 0.002 \\
& Genotype & -0.534 & 0.257 & 0.586 & 4.324 & 0.038 \\
Han Chinese & Body mass index & 0.171 & 0.047 & 1.187 & 13.262 & 0.000 \\
& Alcohol consumption & 0.737 & 0.179 & 2.090 & 16.904 & 0.000 \\
Hei plus Han & Gender & -0.470 & 0.230 & 0.625 & 4.192 & 0.041 \\
& Body mass index & 0.090 & 0.038 & 1.094 & 5.550 & 0.018 \\
& Systolic blood pressure & 0.013 & 0.006 & 1.013 & 5.163 & 0.023 \\
& Alcohol consumption & 0.691 & 0.148 & 1.997 & 21.967 & 0.000 \\
\hline
\end{tabular}

(0.297) than in Liangshan Yi (0.233), the other minority in China (41), and Caucasians $(0.124-0.218)$ in the western countries (28-30,42-44). There were no significant differences in the A allele frequency between Hei Yi Zhuang and Han Chinese in Beijing (0.258) (45), and Singaporean Chinese (0.275) (46). Rare allelic frequency of Caucasians from different nations was similar and significantly lower than that of oriental races, substantiating that this SNP was distinguishing among races, also suggesting that nationalities with similar allelic frequencies may have ancestor homology.

The potential relationships in humans between polymorphisms at the apoA-I -75 bp G/A and plasma or serum lipid levels have been evaluated in a large number of studies. Talmud et al (44) found that A allele induced elevated HDL-C 
and apoA-I levels. This relationship was also demonstrated in many other studies, but with sex-dependency, Jeenah et al (27) and Sigurdsson et al (29) found in British and Icelandic male respectively that A allele confered high serum apoA-I level. Xu et al (30) reported A carriers had higher mean levels of TC, LDL-C, apoB and apoA-I than G homozygotes in Italian boys. Nevertheless, Pagani et al (26) discovered A allele was positively related to HDL-C concentration in Italian female exclusively. In addition, this facilitation of $\mathrm{A}$ allele to elevated serum HDL-C and apoA-I levels was affected by lifestyle factors such as smoking and drinking alcohol. Study conducted on 287 healthy Singaporean Chinese found this facilitation in male non-smoker merely (46). Furthermore, a study (41) on Yi-emigrants in China reported that, alcohol users who carried A allele had notably lower serum HDL-C and apoA-I concentrations than G homozygotes, however, this relationship was reversed in non-drinkers. The $\mathrm{G} \rightarrow \mathrm{A}$ transition could elucidate $18 \%$ of interindividual variations of serum apoA-I levels in non-drinkers of Yi-emigrants. There are also some studies that detected no correlation between the apoA-I -75 bp G/A and serum lipid patterns $(32,47)$. Considerable studies were undertaken to estimate the effect of the apoA-I -75G/A to serum lipid traits of population with basal diseases. In most research, CHD groups had higher AA genotypic frequencies than healthy controls (48-50), TG level of AA homozygotes was higher than that of GG homozygotes (51). In some subsets of male CHD subjects, AA homozygote conferred decreased serum HDL-C concentration $(48,52)$. Two separate studies performed on Australian CHD patients disclosed association between A allele and coronary artery stenosis, moreover, AA genotypic frequency trended to increase by the growing number of stenosed coronary arteries $(42,49)$. In the present study, we showed that the levels of LDL-C and apoA-I in Hei Yi Zhuang were lower in AA or GA genotype than in GG genotype, but the levels of TG was lower in AA genotype than in GA genotype. There were also significant differences in serum TG levels among the three genotypes in Hei Yi Zhuang, but the levels of TG in Han were higher in GA genotype than in GG genotype. The levels of apoA-I in Hei Yi Zhuang and the levels of HDL-C and apoB in Han were significantly correlated with genotype. Hypertriglyceridemia was negatively associated with genotype in Hei Yi Zhuang but not in Han. These contradictory results of all association studies on this SNP, to some extent, demonstrated the generally accepted hypothesis $(32,53)$, which denies direct effect of the G/A substitution on HDL-C and apoAI concentration, but is due to unknown polymorphism(s), nearby or distant, which is in linkage disequilibrium with this apoA-I -75G/A SNP. The reversed effects of $\mathrm{A}$ allele to lipids metabolism between healthy and CHD population indicate that there may be an unknown SNP as genetic marker of CHD absent in normosubjects, which is in linkage disequilibrium with the apoA-I $-75 \mathrm{G} / \mathrm{A}$ transition.

In addition to the effect of genetic factors, serum lipid levels were also influenced by multiple environmental factors. Some epidemiologic surveys have shown that high-fat diet intake, particularly containing abundant saturated fatty acids, raises the blood cholesterol concentrations and predisposes individuals to cardiovascular disease $(54,55)$. Connor et al
(56) also showed significantly positive association between serum concentration of cholesterol and cholesterol constituent of food in a cohort taking low-cholesterol diet. As we reported previously (35-37), the people of Hei Yi Zhuang live in the infertile mountainous area. Their earnings derive mostly from planting corn and paddy. Corn gruel and tortillas are their staple food all the year around. Approximately $90 \%$ of the beverages were corn wine and rum that they brew themselves. In contrast, rice was the staple food in Han. The standard of living in Han was higher than that in Hei Yi Zhuang. The intake of animal fat was also more than that in Hei Yi Zhuang. About $90 \%$ of the beverage was rice wine. Corn was reported as healthy food because it contained abundant dietary fiber and high-quality plant protein (57). High dietary fiber intake can result in a decrease of serum cholesterol levels in healthy and hyperlipidemic subjects (58). Corn oil was a kind of edible oils that is enriched with polyunsaturated fatty acid and monounsaturated fatty acid (59). Suitable intakes of polyunsaturated fatty acids and monounsaturated fatty acids can lower the serum levels of cholesterol and LDL-C $(60,61)$. A potential beneficial effect of dietary monounsaturated fatty acids on HDL-C has also been suggested (61).

In conclusion, the present study shows that there were significant differences in the allele frequency at the apoA-I 75G/A locus between the Hei Yi Zhuang and Han populations. Serum levels of TG, LDL-C and apoA-I in Hei Yi Zhuang were influenced by different genotypes, whereas the levels of TG, HDL-C and apoB in Han were associated with genotypes. The differences in serum lipid levels between the two ethnic groups might be attributed to the interaction of environmental and genetic factors.

\section{Acknowledgements}

This study was supported by the National Natural Science Foundation of China (no. 30360038).

\section{References}

1. Shekelle RB, Shryock AM, Paul O, Lepper M, Stamler J, Liu S and Raynor WJ Jr: Diet, serum cholesterol, and death from coronary heart disease. The Western Electric study. N Engl J Med 304: 65-70, 1981.

2. Martin MJ, Hulley SB, Browner WS, Kuller LH and Wentworth D: Serum cholesterol, blood pressure and mortality: implications from a cohort of 361,662 men. Lancet 2: 933-936, 1986.

3. Kim HK, Chang SA, Choi EK, Kim YJ, Kim HS, Sohn DW, Oh BH, Lee MM, Park YB and Choi YS: Association between plasma lipids, and apolipoproteins and coronary artery disease: a cross-sectional study in a low-risk Korean population. Int J Cardiol 101: 435-440, 2005.

4. Austin MA: Plasma triglyceride as a risk factor for coronary heart disease. The epidemiologic evidence and beyond. Am J Epidemiol 129: $249-259,1989$.

5. Hokanson JE and Austin MA: Plasma triglyceride level is a risk factor for cardiovascular disease independent of highdensity lipo-protein cholesterol level: a meta-analysis of population-based prospective studies. J Cardiovasc Risk 3: 213-319, 1996.

6. Marz W, Scharnagl H, Winkler K, Tiran A, Nauck M, Boehm BO and Winkelmann BR: Low-density lipoprotein triglycerides associated with low-grade systemic inflammation, adhesion molecules, and angiographic coronary artery disease: the Ludwigshafen Risk and Cardiovascular Health study. Circulation 110: 3068-3074, 2004. 
7. Achari $\mathrm{V}$ and Thakur AK: Association of major modifiable risk factors among patients with coronary artery disease - a retrospective analysis. J Assoc Physicians India 52: 103-108, 2004.

8. Durrington PN, Hunt L, Ishola M, Kane J and Stephens WP: Serum apolipoproteins AI and B and lipoproteins in middle aged men with and without previous myocardial infarction. $\mathrm{Br}$ Heart J 56: 206-212, 1986

9. Kwiterovich PO Jr, Coresh J, Smith HH, Bachorik PS, Derby CA and Pearson TA: Comparison of the plasma levels of apolipoproteins $\mathrm{B}$ and $\mathrm{A}-1$, and other risk factors in men and women with premature coronary artery disease. Am J Cardiol 69: 1015-1021, 1992.

10. Graziani MS, Zanolla L, Righetti G, Marchetti C, Mocarelli P and Marcovina SM: Plasma apolipoproteins A-I and B in survivors of myocardial infarction and in a control group. Clin Chem 44: 134-140, 1998.

11. Walldius G, Jungner I, Holme I, Aastveit AH, Kolar W and Steiner E: High apolipoprotein B, low apolipoprotein A-I, and improvement in the prediction of fatal myocardial infarction (AMORIS study): a prospective study. Lancet 358: 2026-2033, 2001.

12. Assmann $\mathrm{G}$ and Schulte $\mathrm{H}$ : Relation of high-density lipoprotein cholesterol and triglycerides to incidence of atherosclerotic coronary artery disease (the PROCAM experience). Prospective Cardiovascular Munster study. Am J Cardiol 70: 733-737, 1992.

13. Young SG: Recent progress in understanding apolipoprotein B. Circulation 82: 1574-1594, 1990.

14. Wilson PW, Abbott RD and Castelli WP: High density lipoprotein cholesterol and mortality. The Framingham Heart Study. Arteriosclerosis 8: 737-741, 1988.

15. Libby P: Managing the risk of atherosclerosis: the role of highdensity lipoprotein. Am J Cardiol 88: N3-N8, 2001.

16. Sviridov D and Nestel P: Dynamics of reverse cholesterol transport: protection against atherosclerosis. Atherosclerosis 161: 245-254, 2002.

17. Assmann G and Nofer JR: Atheroprotective effects of highdensity lipoproteins. Annu Rev Med 54: 321-341, 2003.

18. Brewer HB Jr and Santamarina-Fojo S: New insights into the role of the adenosine triphosphate-binding cassette transporters in high-density lipoprotein metabolism and reverse cholesterol transport. Am J Cardiol 91: E3-E11, 2003.

19. Van Lenten BJ, Navab M, Shih D, Fogelman AM and Lusis AJ: The role of high-density lipoproteins in oxidation and inflammation. Trends Cardiovasc Med 11: 155-161, 2001 .

20. Nofer JR, Kehrel B, Fobker M, Levkau B, Assmann G and von Eckardstein A: HDL and arteriosclerosis: beyond reverse cholesterol transport. Atherosclerosis 161: 1-16, 2002.

21. Barter P, Kastelein J, Nunn A and Hobbs R: High density lipoproteins (HDLs) and atherosclerosis; the unanswered questions. Atherosclerosis 168: 195-211, 2003.

22. Karathanasis SK, McPheroson J, Zannis VI and Breslow JL: Linkage of human apolipoprotein A-I, C-III. Nature 304: 371-373, 1983.

23. Groenendijk M, Cantor RM, De Bruin TW and DallingaThie GM: The apoAI-CIII-AIV gene cluster. Atherosclerosis 157: 1-11, 2001.

24. Tybjaerg-Hansen A, Nordestgaard BG, Gerdes LU, Faergeman O and Humphries SE: Genetic markers in the apo AI-CIII-AIV gene cluster for combined hyperlipidemia, hypertriglyceridemia, and predisposition to atherosclerosis. Atherosclerosis 100: 157-169, 1993.

25. Ordovas JM, Civeira F, Genest J Jr, Craig S, Robbins AH, Meade T, Pocovi M, Frossard PM, Masharani U, Wilson PW, Salem DN, Ward RH and Schaefer EJ: Restriction fragment length polymorphisms of the apolipoprotein A-I, C-III, A-IV gene locus. Relationships with lipids, apolipoproteins, and premature coronary artery disease. Atherosclerosis 87: 75-86, 1991.

26. Pagani F, Sidoli A, Giudici GA, Barenghi L, Vergani C and Baralle FE: Human apolipoprotein A-I gene promoter polymorphism: association with hyperalphalipoproteinemia. J Lipid Res 31: 1371-1377, 1990.

27. Jeenah M, Kessling A, Miller $N$ and Humphries SE: G to A substitution in the promoter region of the apolipoprotein AI gene is associated with elevated serum apolipoprotein AI and high density lipoprotein cholesterol concentrations. Mol Biol Med 7: 233-241, 1990.
28. Paul-Hayase H, Rosseneu M, Robinson D, van Bervliet JP, Deslypere JP and Humphries SE: Polymorphisms in the apolipoprotein (apo) AI-CIII-AIV gene cluster: detection of genetic variation determining plasma apo AI, apo CIII and apoA IV concentrations. Hum Genet 88: 439-446, 1992.

29. Sigurdsson G Jr, Gudnason V, Sigurdsson G and Humphries SE: Interaction between a polymorphism of the apoA-I promoter region and smoking determines plasma levels of HDL and apoA-I. Arterioscler Thromb 12: 1017-1022, 1992.

30. Xu CF, Angelico F, Del Ben M and Humphries SE: Role of genetic variation at the apoAI-CIII-AIV gene cluster in determining plasma apoA-I levels in boys and girls. Genet Epidemiol 10: 113-122, 1993.

31. Smith JD, Brinton EA and Breslow JL: Polymorphism in the human apolipoprotein A-I gene promoter region. Association of the minor allele with decreased production rate in vivo and promoter activity in vitro. J Clin Invest 89: 1796-1800, 1992.

32. Barre DE, Guerra R, Verstraete R, Wang Z, Grundy SM and Cohen JC: Genetic analysis of a polymorphism in the human apolipoprotein A-I gene promoter: effect on plasma HDLcholesterol levels. J Lipid Res 35: 1292-1296, 1994.

33. Yin RX, Chen YM, Pan SL, He FB, Liu TW, Yang DZ, Wu JZ, Yao LM, Lin WX, Li RS and Huang JD: Effects of demographic, dietary, and other lifestyle factors on the prevalence of hyperlipidemia in Guangxi Hei Yi Zhuang and Han populations. Eur J Cardiovasc Prev Rehabil 13: 977-984, 2006.

34. Yin RX, He FB, Pan SL, Yang DZ, Lin WX, Liu TW, Chen YM, Wu JZ, Yao LM and Huang JD: Prevalence of hyperlipidemia and its risk factors for the middle-aged and elderly in the Guangxi Hei Yi Zhuang and Han populations. J Investig Med 54: 191-200, 2006.

35. Yin RX, Li RS, Lin WX, Yin DZ and Pan SL: Effect of the MTP-493 G/T polymorphism on the lipid profiles of the Guangxi Hei Yi Zhuang and Han populations. Eur J Lipid Sci Technol 108: 561-568, 2006.

36. Yin RX, Wang Y, Chen GQ, Lin WX, Yang DZ and Pan SL: Lipoprotein lipase gene polymorphism at the Pvu II locus and serum lipid levels in Guangxi Hei Yi Zhuang and Han populations. Clin Chem Lab Med 44: 1416-1421, 2006.

37. Yin RX, Chen GQ, Wang Y, Lin WX, Yang DZ and Pan SL: Effect of the 3'APOB-VNTR polymorphism on the lipid profiles in the Guangxi Hei Yi Zhuang and Han populations. BMC Med Genet 8: 45-58, 2007.

38. Civeira F, Pocovi M, Cenarro A, Garces C and Ordovas JM Adenine for guanine substitution -78 base pairs $5^{\prime}$ to the apolipoprotein (APO) A-I gene: relation with high density lipoprotein cholesterol and APO A-I concentrations. Clin Genet 44: 307-312, 1993.

39. Hansson L, Hedner T and Himmelmann A: The 1999 WHOISH Guidelines for the Management of Hypertension - new targets, new treatment and a comprehensive approach to total cardiovascular risk reduction. Blood Press 1 (Suppl): 3-5, 1999.

40. Zhou B: Predictive values of body mass index and waist circumference to risk factors of related diseases in Chinese adult population. Zhonghua Liu Xing Bing Xue Za Zhi 23: 5-10, 2002.

41. Zhao Q, She M, Shen $\mathrm{P}$, Zhang $\mathrm{H}$ and Zhou M: Interaction of alcohol and the $G$ to A substitution at the promoter region of the apolipoprotein AI gene in determining plasma apolipoprotein AI levels in Yi and Han Chinese. Chin Med J (Engl) 113: 471-474, 2000 .

42. Wang XL, Badenhop R, Humphrey KE and Wilcken DE: New MspI polymorphism at +83 bp of the human apolipoprotein AI gene: association with increased circulating high density lipoprotein cholesterol levels. Genet Epidemiol 13: 1-10, 1996.

43. Rigoli L, Raimondo G, Di Benedetto A, Romano G, Porcellini A, Campo S, Corica F, Riccardi G, Squadrito G and Cucinotta D: Apolipoprotein AI-CIII-AIV genetic polymorphisms and coronary heart disease in type 2 diabetes mellitus. Acta Diabetol 32: 251-256, 1995.

44. Talmud PJ, Ye S and Humphries SE: Polymorphism in the promoter region of the apolipoprotein AI gene associated with differences in apolipoprotein AI levels: the European Atherosclerosis research study. Genet Epidemiol 11: 265-280, 1994.

45. Wang LY, Gu Y, Wu GX, Wang W, Liu J, Pan XT, Wu ZS and Guo XZ: Apolipoprotein AI gene polymorphism and serum lipid levels in Beijing Han population. Chin J Pathophysiol 14: 478-483, 1998. 
46. Saha N, Tay JS, Low PS and Humphries SE: Guanidine to adenine (G/A) substitution in the promoter region of the apolipoprotein AI gene is associated with elevated serum apolipoprotein AI levels in Chinese non-smokers. Genet Epidemiol 11: 255-264, 1994.

47. De Franca E, Alves JG and Hutz MH: APOA1/C3/A4 gene cluster variability and lipid levels in Brazilian children. Braz J Med Biol Res 38: 535-541, 2005.

48. Cheng AJ, Mao YM, Cui RZ and Wang PX: Study on the relationship between apo-AI gene promoter polymorphism and coronary heart disease and serum lipid levels. Tianjin Med J 32: 327-329, 2004.

49. Liu SX, Wilcken D and Yang JJ: Studies on the association of apolipoprotein AI gene polymorphism with coronary heart disease. Prev Treat Cardio-Cerebral-Vascular Dis 1: 10-12, 2001.

50. Yang SL, He BX, Hong XF, Zou YC and Liu MJ: G to A and/or $\mathrm{C}$ to $\mathrm{T}$ transition in the promoter region of the apolipoprotein $\mathrm{AI}$ gene in Chinese Xinjiang Uygur and Han with coronary artery disease. South China J Cardiol 7: 155-159, 2001.

51. Liu R, Deng JL, Bai H, Liu Y, Zhu H and Liu BW: Apolipoprotein $\mathrm{AI}$ gene $\mathrm{G} \rightarrow \mathrm{A}$ substitution at position -78 in promoter and $\mathrm{C} \rightarrow \mathrm{T}$ substitution at position +83 in intron 1 in relation to coronary heart disease in Chinese population. Journal of West China University of Medical Sciences (J WCUMS) 33: 336-339, 2002.

52. Chen Q, Mao YM, Cui RZ, Cheng JX, Zhao YX and Zhu TH: The relationship between $\mathrm{G} \rightarrow \mathrm{A}$ substitution at position $-78 \mathrm{bp}$ in promoter of apo AI gene and coronary heart disease. J Clin Cardiol (China) 17: 149-151, 2001.
53. Minnich A, De Langavant G, Lavigne J, Roederer G, LussierCacan $S$ and Davignon $J$ : $G \rightarrow A$ substitution at position -75 of the apolipoprotein A-I gene promoter. Evidence against a direct effect on HDL cholesterol levels. Arterioscler Thromb Vasc Biol 15: 1740-1745, 1995.

54. Hegsted DM, McGandy RB, Myers ML and Stare FJ: Quantitative effect of dietary fat on serum cholesterol in man. Am J Clin Nutr 17: 281-295, 1965.

55. Yu-Poth S, Zhao G, Etherton T, Naglak M, Jonnalagadda S and Kris-Etherton PM: Effects of National Cholesterol Education Program's Step I and Step II dietary intervention programs on cardiovascular disease risk factors: a meta-analysis. Am J Clin Nutr 69: 632-646, 1999.

56. Connor WE, Cerqueira MT, Connor RW, Wallace RB, Malinow MR and Casdorph HR: The plasma lipids, lipoproteins, and diet of the Tarahumara Indian of Mexico. Am J Clin Nutr 31: 1131-1142, 1978.

57. Dong W, Ma X, Zhang D and Yu S: Effect of maize embryo on delaying aging. Food Sci 23: 95-97, 2002.

58. Lairon D: Dietary fibres: effects on lipid metabolism and mechanisms of action. Eur J Clin Nutr 50: 125-133, 1996.

59. Liu Y, Zhang L and Wu Y: The dietary therapy for hyperlipoidemia complicated with NIDDM. Chin J Clin Nutr 3: 174-176, 1995.

60. Zhang Y, Zhou Y, Wu F and Zhang M: The comparative effects of maize oil and lard on blood lipids serum glucose and brain lipofuscin in rats. Acta Nutrimenta Sinica 18: 274-279, 1996.

61. Grundy SM and Denke MA: Dietary influences on serum lipids and lipoproteins. J Lipid Res 31: 1149-1172, 1990. 